\title{
Shorter or longer text in Ezekiel 6: The role of genre
}

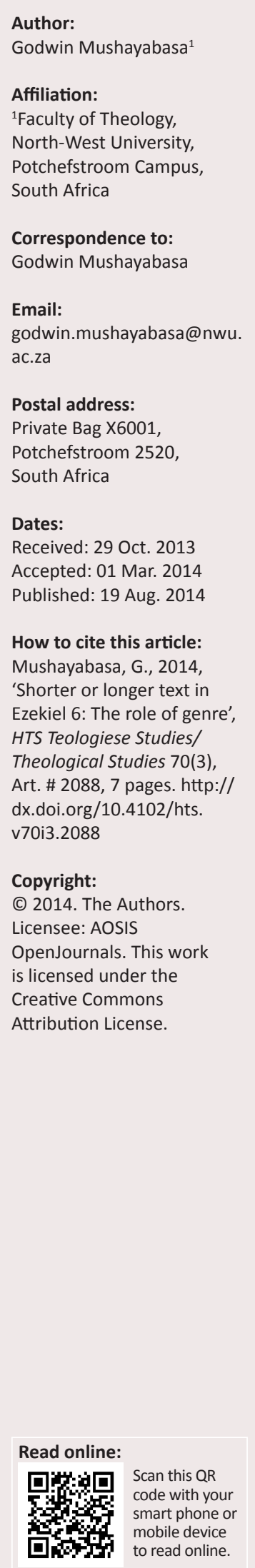

The text of Ezekiel continues to present some challenges to students studying it. This is in view of what one school of thought identify in the Ezekiel text as extensive redactions and revisions, whilst another school of thought is hesitant to subject the Masoretic Text (MT) to such critical analysis. Amidst these differing viewpoints, I have discussed by means of literary analysis, the possibility that chapter 6 of Ezekiel may have been intended as a prophetic poetic message, or was later edited to conform to the genre of prophetic poetry. This is in the light of the so-called repetitions or 'additions' reflected in the MT if compared against the LXX, as well as the general problems associated with the Hebrew text of Ezekiel. The findings indicate that the text of Ezekiel 6 probably already had a complete theological corpus when it left the hand of the prophet Ezekiel or those who penned his words down. However, scribes saw it necessary to restructure, organise and colour the prophetic oracle in a literary form and structure they thought was necessary. This finding could be vital for solving literary and text critical problems in Ezekiel.

\section{Introduction}

It is well-known that the text of Ezekiel is plagued by serious text critical and literary problems. Thus Cooke (1936:xl) has made the commonly quoted remark: 'In the Hebrew Bible, perhaps no book, except 1 and 2 Samuel, has suffered more injury to its text than Ezekiel' (cf. Lust 2006:155 and Van Rooy 2004:140). The Ezekiel text of the Greek translation (GT) is shorter than the Masoretic Text (MT) by about 4\% - 5\%, the expectation being that a manuscript such as Papyrus 967 would be even shorter (Lust 2006:160-161). Indeed, chapter 2 of Ziegler's Ezekiel edition, ${ }^{1}$ when compared to the MT, appears to be about 10\% shorter! However, Ezekiel 6 in the same edition appears to be one of those exceptionally short chapters of the GT - about $28 \%$ shorter than the MT text. Notably, the 'additional text' ${ }^{\prime 2}$ in Ezekiel 6 does not occur in the same place but appears as insertions (pluses) scattered throughout the chapter. ${ }^{3}$ Two major views have dominated academia's position on Ezekiel towards the end of the 20th century. According to the first view, the text of Ezekiel contains many layers of redactions or revisions by redactors who worked on the book, resulting in a longer text reflected in the MT. Consequently, one needs to separate these different layers or stratifications from the more important, authentic text of the author of Ezekiel (Joyce 2007:14). Some of the proponents of this view include Garscha (1974), Schulz (1969) and Pohlmann (1996) (Joyce 2007:14; cf. Pohlmann 1996).

On the other opposite spectrum of the debate is the view that literary studies should give up trying to find layers and, if at all possible, the so-called text of the original author of Ezekiel. In other words, the Ezekiel text should be accepted and studied as is for what may confidently be identified as textual errors and corruptions in the proto-Masoretic textual tradition. Greenberg (1983) and Hummel (2005) are some of those advocating for this view.

Perhaps between these two main views is a vein of thought which I may, for the purposes of this article, refer to as a midstream view. This view falls properly within the domains of textual and literary criticism, and its main proponents are Lust (1986) and Tov (1999) (cf. Joyce 2007). In essence, they point out that the longer MT text does not represent corruptions or revisions as such, but is a witness to the literary growth of the book (Tov 1999:397; cf. Van Rooy 2004:142). The additional text (excluding transmission errors) is therefore to be seen as part of a later stage in the development of successive editions of the book of Ezekiel (Van Rooy 2004:142). ${ }^{4}$ The matter of authenticity or inauthenticity is not the main issue (Dillard \& Longman 1994:317). According 1.A critical edition based on Papyrus 967 and Codex Vaticanus (B); main witnesses to the pre-Hexaplaric Old Greek text (cf. Van Rooy 2004:142)

2.I refer in this article to that text which is in the MT but missing in the LXX (967) as the 'additional text'.

3.Ezekiel 6 in the MT is apparently one of the chapters considered by Zimmerli as having been perfectly preserved (Lust 2006:155).

4.The Oxford Hebrew Bible project, currently underway, has been modelled in line with these presuppositions (Van Rooy 2004). 
to Lust (2006:159-160), the study of this phenomenon falls outside of the domain of textual criticism, being rather a subject belonging to studies of literary criticism. Thus neither the MT text nor the shorter Greek Translation (GT) should be taken as representing a faithful text and therefore deserving preference.

It is roughly within the context of the midstream view that the present study takes place. In the current article, the aim is to study the 'additional text' as the work of redactors; Lust (2006:159) referred to the additional text as 'glosses'. It is necessary to find out the intention of the these redactors by looking at the form which their insertions took and the literary effect (mainly in terms of genre) that such insertions had on the purported earlier text. Consequently, the research will attempt to characterise the final text as it appears in the present MT text in terms of genre. Such a critical literary approach on the study of the differences in textual traditions could provide answers that could not otherwise be obtained by a mere listing of the differences between the MT and the GT texts. Finally, such a study could contribute to the knowledge in terms of the nature of the literary development that took place between the tradition represented in the GT and that represented in the MT text.

\section{Nature of the additions and their effect}

\section{Repetitiveness and distribution of the insertions}

A mere reading of Ezekiel 6, even in translation, will immediately call attention to the presence of numerous repetitions in the text (cf. Joyce 2007:9; Hummel 2005:7, 200); for example, in verses 4-6 and 13, there are several repeated expressions with slight variations. At some places the text seems to be verbose with numerous phrases that border on redundancy. Furthermore, the distribution of the additions is such that they are evenly spread throughout the chapter, save for the introductory and concluding sections of the chapter (vs. 1-3 and 14 respectively), which contain no observable additions. The immediate impression that one gets in reading this text therefore is that there is a tendency to play with words and emphasise certain aspects, resulting in a text form that has much in common with the biblical poetic genre.

Repetition is certainly not a characteristic feature of chapter 6 alone but of large parts of Ezekiel (Joyce 2007:9). However, one would like to believe that for each section of the book, such repetitive tendencies did not happen randomly and without purpose. For example, Joyce makes reference to the numerous repetitions in Ezekiel 36, an antithetic chapter to Ezekiel 6. There he finds the introductory formula 'thus says the Lord God' occurring no less than seven times between verses 2 and 13. Yet few of those so-called repetitions are reported as missing in the GT. In fact, the text of Ezekiel 36:1-22 has far fewer additional texts than that of Ezekiel 6. The text which might be additional in Ezekiel 36 does not show any indications that it was used to shear the text towards a poetic style. ${ }^{5}$ Indeed Ezekiel 36 reads without any doubt as a prosaic oracle. One would like to believe therefore that whilst there are repetitions throughout the book of Ezekiel, such repetitions did not happen uniformly; neither did they occur randomly, without purpose or design. It is here then that the question can be asked: 'Could it be that Ezekiel 6 was viewed as a poetic text at some point during the literary development of the text?'

\section{Effect of the additional text on style}

From a preliminary study of the additions in the text of Ezekiel 6, one will get an impression that the additions were made to either retain or even achieve a rhythmic style, at least in terms of parallelism. An analysis of some of the styles in this text will provide grounds for such a supposition; for example, the prophetic oracle in verse 3 contains an opening command introducing the oracle, 'say to the mountains of Israel'. This introductory clause is then further expanded in the form of two pairs of parallel lines. After this comes the conclusion to the introductory formula, which can also be understood as the gist or the actual introductory message of Ezekiel 6. What is particularly striking is the parallelism of the 'enclosed' parallel lines. The first pair of lines (or versets) display clear semantic, lexical and phonetic parallelism.

However, such parallelism may be attributed to mere repetition. Nevertheless, repetition is an important characteristic of biblical poetry. The stylistics of the second pair in verse 3 is dominated by antithetic parallelism: 'To the mountains and to the hills - to the ravines and to the valleys'. There seems to be no additional text in this verse. Yet this opening part of the chapter is of an invitingly poetic structure and rhythm. What follows in the rest of the chapter is perhaps an attempt by the redactors to imitate this form and give a similar rhythm to the rest of the oracle which otherwise may not originally have had this kind of rhythm.

In that regard, it seems verses 4 and 5 stand together stylistically and may be discussed together. The shorter text of this verse (GT reading) is provided in Table 1.

The corresponding MT text (Table 2) contains additional text at two points (underlined), perhaps reflecting a redactor's attempt to balance the lines thereby producing the structure in Table 2.

It is interesting to note the semantic progression and phonetic resonance between ונשמו [and they shall be desolate] and ונשברו [they shall be crushed] in the first line of verse 4 . There is also a marked phonetic parallelism between the last line of verse 4 and the first line of verse 5 considering the Hebrew beginning and endings of the clauses. However, the insertion of verse $5 \mathrm{a}$ is problematic for a poetic style if both verses 4 and 5 are juxtaposed. It seems that the two verses

5.There is a long omission in Papyrus 967 from Ezekiel $36: 23 c$ to verse 38 if compared against the MT. This omission has been thought to be a result of homoteleiton (Goshen-Gottstein \& Talmon 2004). However, others attribute the additional text in the MT to the fact that Papyrus 967 represents an earlier literary stage in the in the MT to the fact that Papyrus 967 represents an earlier literary stage in the
composition of the biblical text, and thus a text which once lay in the Hebrew Manuscripts as well (Joyce 2007:9). 
TABLE 1: Shorter Greek text of Ezekiel 4-5.

\begin{tabular}{|c|c|}
\hline Greek text & Translation \\
\hline 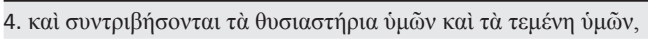 & 4. And your altars, and your sun-pillars shall be broken down, \\
\hline 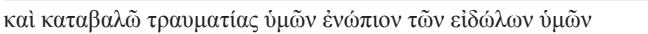 & And I will throw down your slain before your idols. \\
\hline 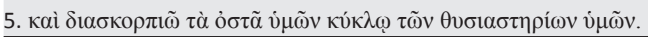 & 5. And I will scatter your bones around your altars. \\
\hline
\end{tabular}

TABLE 2: Longer Masoretic text of Ezekiel 4-5.

\begin{tabular}{|c|c|c|}
\hline Hebrew text & & Translation \\
\hline & 4. & 4. And your altars shall become desolate, ${ }^{\dagger}$ \\
\hline & 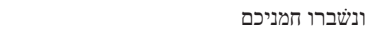 & And your sun-pillars shall be crushed, \\
\hline & והפלתי חלליכם לפני גלוליכם & And I will throw down your slain before your idols. \\
\hline & 5 ונתתי את־פגרי בני ישראל לפני גלוליהם & 5. And I will lay the corpses of the children of Israel before their idols, \\
\hline & וזריתי את־עצמותיכם סביבות מזבחותיכם & and I will scatter your bones around your altars. \\
\hline
\end{tabular}

$\dagger$, Biblia Hebraica Stuttgartensia (BHS) (2003) editors cite the second verb [broken down] in verse 4 of the MT text as being omitted in the LXX. However, it appears that this second verb was actually the one translated in the LXX. The first verb ונשמו [deserted] is the one that appears to be missing in the LXX. There is particularly strong evidence for the difference of opinion expressed here and this will be dealt with at length in a separate article.

would read better poetically without verse $5 \mathrm{a}$. However, it might have happened that a redactor saw each of the verses as standing alone, and thus the need arose to give balance to verse 5 rhythmically. The addition of verse 5 a would then make sense as helping the reading of verse 5 poetically. Stromberg (2008:71-72) and Greenberg (1983:132) contend that the addition in verse $6: 5 \mathrm{a}$ was a result of an editor's explanatory note on the stretched reference of the figurative address, 'to the mountains $[\ldots]$ ', beginning in verse $6: 3$. This latter editorial addition could have been aided by the parallel relation between verse $6: 4 \mathrm{~b}$ (as well as the larger context of Ezekiel 6) and Leviticus 26:30. In contrast, I argue that it could rather have been the need to present the text in a specific genre that prompted the editor to refer to other parts of the Old Testament such as Leviticus 26.

Another example worth mentioning is the parallelism and structure in verse 6 . The parallelism in this verse is mainly grammatical and phonetic in nature and thus not likely to be apparent in translation. A reconstructed text of this verse will yield five lines with the first line being a kind of an introduction to the verse. The introductory phrase (numbered as $a$ in Table 3) in turn introduces four versets, where each of the versets can further be divided into two parts. There are thus eight versets in total, numbered $b$ to $i$ in Table 3.

The first set of four lines are characterised by the use of the Qal imperfect conjugation, whilst the second set of four is characterised by the use of the waw consecutive + Nifal perfect conjugation. The first set of four contains two copulas, one joining the first two versets and the second copula joining the second two. The second set of four all have the waw consecutive prefixed to them so that the initial words have a kind of a sound alliteration or sound parallelism. The middle two nouns, namely מזבחותיכם [your altars] and גלוליכם [your idols] take two verbs each. ${ }^{6}$ Furthermore, line $b$ remarkably parallels $c$, and $f$ parallels $g, h$ and $i$ in terms of sound alliteration. A rhythmic impression is thus immediately achieved in the Hebrew text (mostly not apparent in the translated text). The structure of the four lines in terms of syllable count (each divided into two) is $6+7,6+9,8+8$ and $8+6$. Thus a compact poetical structure is achieved in this verbally concentrated verse.

6.This syntactic style has also been noted by Allen (1994:82).
TABLE 3: Poetic stylistics in Ezekiel 6:6.

\begin{tabular}{|c|c|c|c|}
\hline $\begin{array}{l}\text { Versets in } \\
\text { Ezekiel 6:6 }\end{array}$ & Hebrew text & Verb analysis & Translation \\
\hline $\mathrm{a}$ & בכל מושבותיכם & (Introductory line) & In all your dwelling places \\
\hline$b$ & הערים תחרבנה & QAL. IMPF & the cities will waste \\
\hline c & והבמות תישמנה & QAL. IMPF & $\begin{array}{l}\text { and the high places will be } \\
\text { desolate }\end{array}$ \\
\hline$d$ & למען יחרבו & QAL. IMPF & So that they will waste \\
\hline e & ויאשמו מזבחותיכם & QAL. IMPF & $\begin{array}{l}\text { and your altars will be } \\
\text { desolated }\end{array}$ \\
\hline f & ונשברו & $W C+N I F$. PERF & and they will be broken down \\
\hline $\mathrm{g}$ & ונשבתו גלוליכם & WC+ NIF. PERF & and your idols will cease \\
\hline h & ונגדעו חמניכם & WC+ NIF. PERF & $\begin{array}{l}\text { and your sun pillars will be } \\
\text { hewn down }\end{array}$ \\
\hline i & ונמחו מעשיכם & WC+ NIF. PERF & $\begin{array}{l}\text { and your works will be } \\
\text { blotted out }\end{array}$ \\
\hline
\end{tabular}

IMPF, imperfect; WC, waw consecutive; PERF, perfect.

The additions, which are our main concern, are not without significance here. The additions include one Qal imperfect verb in line $d$ (יחרבו; they will waste), two Nifal perfect verbs in lines $f$ and $i$ (ונשברו; they will be broken down) (משמונ; they will be blotted out) and a noun in line $i$ (מעשיכם; your works). Without these additional words, this impressive parallelistic pattern here would become severely warped. More examples of a similar nature can be identified especially in verses 12-13. It appears thus that the additional text in the MT seems to enhance what only appears to be a faint poetical colour in the shorter GT.

\section{Effect of the additions to the message of the shorter text}

The shorter Ezekiel 6 text without the so-called additions makes good sense and does not need the 'added text' to have meaning. A consideration of verses 3-6 will give an immediate answer to the effect that the additions do not add any meaningfully unique information to the text. It may confidently be ascertained that none of the identified additions in Ezekiel 6 adds hermeneutically critical information to the text as a whole. At some points in the text, it will appear as if there is indeed new information being added to that particular verse, but on referring to the rest of the verses in the chapter, it will become evident that the information that appears to have been added by the addition, already occurs in another verse within the chapter (cf. an example in the section below). Therefore the additional text is in the 
form of repetitions or rephrased phrases and clauses already occurring in the chapter. This aspect makes the additions look like garnishments to the shorter text. We noted earlier that the shorter text itself is not without stylistics, although they are not quite as marked as they are in the longer text. It appears therefore as if the redactor(s) of Ezekiel 6 added to the text and simply further developed what patterns they already saw apparent in their primary text, careful not to add new information to this primary text. It is also possible that the prophet Ezekiel could have made a first draft which he reworked into a final product himself, thereby highlighting a poetic style in his finished product which had been blurred in an earlier script (cf. Hummel 2005:6; Joyce 2007:45-46).

\section{Effect of the additions to the understanding (exegesis) of the shorter text}

This is certainly a more difficult question to deal with. Of the so-called additions in Ezekiel 6, nearly all do not seem to point towards providing interpretation or towards explanation of the text. However, additions to verse 10 may present us with a challenge in this regard. The MT text of verse 10 when translated reads as follows: אל־חנם) דברתי לעשות להם הרעה הזאת (וידעו (וידעו כי־אני יהוה לא (And they will know that I Yahweh have not spoken in vain, to do to them this distressing thing].

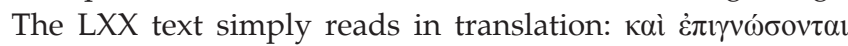

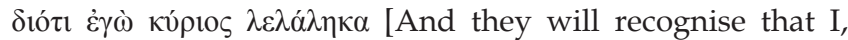
the Lord, have spoken] (cf. Pietersma \& Wright 1989). The additional text in the MT might be considered exegetical in that whilst the Lord says that he has spoken, such speaking is not speech in vain or for nothing, but that Yahweh would actually perform the distressing thing that he had spoken. It is therefore not a matter of simply speaking, but of executing the words of the prophecy. Yet all this information is fully implied in the shorter, unexpanded LXX text. The only way that the Israelites will recognise that Yahweh has spoken is when what he foretells comes to pass. This will happen when he practically does to them the distressing thing he foretells through Ezekiel. The extended version in the MT in verse 10 is then simply a clarifying expansion of the shorter text reflected in the LXX, perhaps with influence from 14:23 (cf. Tov 1999:404-405).

Again, I will consider another case, namely the possibility that the additions in verses 4 and 5 were meant to be exegetical explanations to the shorter text (Table 4).

In terms of addition $a$, the original text (LXX) probably used one verb to describe what shall happen to two objects: altars and sun-pillars or shrines. However, the MT text emerges with two verbs; the second verb apparently (which comes first in the verse) adds more information. Not only will they be broken down, but they will also be desolated or demolished (cf. NIV). However, the idea of desolating or demolishing of the high places (perhaps including also altars) is clearly stated again in verse 6 (cf. Allen 1994:81-82). Furthermore, addition $b$ in verse 5 seems to be a recasting of the last line in verse 4: 'And I will throw down your slain before your idols'. Greenberg (1983:132) and Stromberg
(2008:71) are of the opinion that 'the slain' in verse 4 is a term interpreted as 'the children of Israel' in addition $b$ (v. 5), thus proving that addition $b$ is an exegetical addition (Greenberg 1983:132; Stromberg 2008:71). Indeed, the presence of an exegetical element in the additional text in verse 5 must be acknowledged, but that does not necessarily rule out the possibility that the initial motivation for the addition could have been stylistic rather than exegetical.

In Ezekiel 6:6, the profuse use of semantically equivalent verbs such as תחרבנה [they will waste], תישמנה [they will be desolate], יחרבו [they will waste] and ויאשמו [they will be desolate] with nouns from identical semantic domains (such as altars, shrines, high places, idols and incense burners) may point towards an intention to be stylistic with words rather than to give critically new information. The same trend is traceable in Ezekiel 6:9, 10, 12 and 13. Tov (1999) attempted a study of additional text in the MT against the LXX for the whole book of Ezekiel. He observed that the types of pluses in the MT text included exegetical additions, contextual clarification and new material (Tov 1999:401-408 and 1997:250). He lists the addition of the adjective רעות [evil] to the noun תועבות [abomination] in Ezekiel 6:11 as an exegetical addition, the only exegetical addition he cites in Ezekiel 6. However, one might argue that the noun תועבות [abomination] by itself already carries the connotation of 'evil' so that the adjective רעות [evil] appears to be unnecessary semantically.

In terms of additions to any text, influence in meaning on an original text, although unwanted, may be inevitable. However, what appears to be the major purpose of the additional words in Ezekiel 6 is the dressing of the text to result in a certain appeal to the reader, which in my opinion, should have been a poetical appeal!

\section{Typifying the genre of Ezekiel 6 Ezekiel 6 as a poetic text}

It remains to be verified whether Ezekiel 6 does indeed conform to known standards of what can be understood as biblical poetry, and specifically prophetic poetry, seeing that a slant towards a poetic genre has been detected. Standard principles of describing biblical Hebrew poetry continue to elude scholars, especially from the context of our western understanding of the literary phenomenon that is poetry. This problem is further compounded by the fact that within the corpus of what may be called Hebrew poetry, a variety of genres exist so that each type requires to be identified and typified (cf. Alter 1985:ix). Some scholars are so cautious about differentiating biblical prose from poetry that they rather propose that the distinction between the two in the Hebrew Bible should be one of a continuum - a line between poetry and prose rather than that of definite categories (Dillard \& Longman 1994:27; Freedman 1980:2). Similarly, the quest to find the key to Hebrew poetical metrics has proved futile (Dillard \& Longman 1994:28; Freedman 1980:6). As Freedman (1980:4) has noted, even the Masoretes seem not to have recognised the difference between prose and poetry except where tradition had preserved it in stichometric 
TABLE 4: The additional text in Ezekiel 6:4.

\section{MT (Translation)}

4. And your altars (a) shall become desolate,

and your sun-pillars shall be broken down,

and I will throw down your slain before your idols.

5. (b) And I will lay the corpses of the children of Israel before their idols, and I will scatter your bones around your altars

\section{LXX (Translation)}

4. And your altars, and your sun-pillars shall be broken down,

and I will throw down your slain before your idols.

5. And I will scatter your bones around your altars. writing, or in some other recognisable format. Nevertheless, available studies on Hebrew poetry have attempted some descriptions and suggested some principles. These will provide, at this stage, sufficient guidelines to decide on the nature of the Ezekiel 6 text and perhaps the motive, if any, behind 'the additional text' in the MT. Because the differentiation of poetry from prose normally takes the form of long and detailed descriptions (Alter 1985; Berlin 2008; Freedman 1980), we will not attempt to make such description in this article, but will refer to those aspects that are perhaps cardinal for identifying differences and therefore important for deciding the matter at hand.

\section{Rhythm}

In terms of structure or what others call rhythm of the Hebrew verse, the text of Ezekiel 6 has what appears to be a mixed genre. There are sections which are prosaic in form and style. The introductions of verses 1-3a, for example, are narrative in form, and similarly verses 9 and 14 . The number of syllable count for the versets (tentatively reconstructed) ranges between 6 and 10 per verset for those lines that may be considered poetic within the chapter. Although this range is considered too large, it is not uncommon to the genre of biblical prophetic poetry. As Freedman (1980:2) has remarked, 'many poems do not seem to have clear-cut metrical or strophic patterns and may never yield to this sort of analysis'. Freedman (1980:2) remarks further that biblical poets seem not to have been restrained by matters of metrics in their works. In any case, symmetry is not altogether absent from the lines of Ezekiel 6, if only the stylistics of the author can carefully be discovered and understood. A reconstructed structure of the lines of Ezekiel 6 therefore forms what may loosely resemble the structure of at least prophetic poetry of the Hebrew Bible.

Alter (1985:6), in his attempt to map a distinction between poetry and any other kind of genre, states that once one perceives that a verbal sequence has a sustained rhythm that is formally structured according to a repeated operating principle of organisation, that person becomes aware of the genre that is poetry. One of the most significant effects of meter or rhythmic elements (principles of formal structure) in poetry is to inform the reader that he is being confronted by poetry and not by anything else. Meter, ${ }^{7}$ as Alter puts it, serves as a frame separating the poem from a 'ground' of less highly structured speech. The rhythm of biblical poetry can be determined by any one or a combination of the elements, such as syntax, semantics, or accentuations so that one can talk of a 'free rhythm'. Variations of elements

7.It should be noted in this case that what Alter refers to as 'meter' is not the same as the meaning implied when attached to the Greco-Roman system of carefully regulated sequences of vowel quantities, but rather the continuously present frame of a formal structure (i.e. parallelism of meaning, syntax and rhythm). or combinations of elements can be employed even in a single poem (Alter 1985:6-8; Dillard \& Longman 1994:29). With these guidelines in mind, we have already found that Ezekiel 6 contains sections structured into some kind of rhythm by the parallelism of such elements as semantics, syntax and phonetics (e.g. vs. 3-6 and 12-13). Syllable count also seems to be another determining factor, although in the present analysis, such a factor has only been preliminarily studied. In this regard, Ezekiel 6:12-14 may serve as an example, where although the parallelism of grammatical elements is weak, the syllable arrangement in the lines may be indicative of a rhythmic structure of poetry.

\section{Style}

It appears that in distinguishing Hebrew poetry from prose, we should take note of the fact that poetic texts can be understood as being what narrative or prose texts are not. In prose, the concept of time as well as of sequence and consequence is very important, but not in poetic writing. In poetry progression or linear thinking tends to be rather weak. Although Alter (1985) has identified what he calls a structure of intensification, narrativity, and progression or heightening between poetical lines (Alter 1985:32-36, 22, 171-172), one rather finds the tendency to dwell on a single thought, that is explored in its various dimensions. Alter (1985:19) calls this focusing, specification, or concretisation. ${ }^{8}$ All these elements are present in Ezekiel 6 to some extent. Ezekiel 6 is not a chronological account of the punishments that Yahweh shall inflict on Israel in the future. Time and progression though present, are not essential in the passage. Linguistic elements that tend to heighten the aspect of progression and thus narrativity are those such as a result clause (v. 6a), temporal clauses (Ezk 6:8 and 6:13), and the concluding formula 'and you will know that I am Yahweh' (Ezk 6:7, 6:10, 6:13 and 6:14). On the other hand, the repetitiveness of this text gives the impression that the prophet is simply dwelling on a few thoughts, thus focusing on and concretising Yahweh's judgement on Israel and on its idolatry, in a manner typical of poetic style. In this sense then, Ezekiel 6 appears to have both poetic and prosaic (specifically narrative) characteristics. However, the poetic colour is slightly stronger, especially in the longer MT text.

Parallelism is the dominant poetic feature in Ezekiel 6. The sixth chapter is replete with what we may call poetic parallelism as we have observed. Such parallelism is doubtless brought to the fore by the numerous repetitions in this section of Ezekiel; the parallelism comes in many forms (i.e. semantic, syntactic, lexical, phonological and antithetic).

8.Cf. Alter (1985:27-61). In Alter's case, this applies specifically with semantic parallelism, but I should like to think that it is the case with syntactic and lexical parallelism as well. 
Parallelism and terseness have been identified as the main characteristics of biblical poetics (Berlin 2008:4-17). Gray (1972:236) identifies parallelism and rhythm as the main forms of Hebrew poetry. Whilst the text of Ezekiel 6 is cast in a lot of parallelism, there is little confidence in it in terms of rhythm or terseness.

\section{Language and grammar}

Poetic texts are generally very generous in the use of some parts of speech (such as metaphorical language) whilst on the other hand they use other parts of speech stringently (cf. Dillard \& Longman 1994:27, 29). The dominant poetic feature of Ezekiel 6, in terms of language and grammar, is perhaps that of ellipsis. Metaphorical language is limited to the identification of the Israelites with the geographical 'mountains, hills, ravines and valleys'. The message is thus mostly stated in a clear, non-paradoxical manner, profuse with vivid or graphic imagery of the wrathful vengeance that Yahweh would inflict on the rebellious nation. On syntactical components, there is a profuse use of conjunctions, including relative particles, the waw copulative and waw consecutive. There also tends to be a high number of complex sentences, such as coordinate, consecutive, final, temporal and adverbial clauses. As a result of these linguistic features, the reading of the text may approximate to that of a prosaic passage (cf. Freedman 1980:2-3; Dillard \& Longman 1994:27).

\section{Ezekiel 6 as a prophetic oracle}

From the beginnings of prophecy in Israel, at least until the exile, it is thought that poetry was the central medium of prophecy. The pattern should have continued after the exile although there is less certainty from that period onwards (Freedman 1980:18-19).

Alter (1985:27) echoes this understanding, stating that whilst a good deal of poetry has been mixed with prose in books of Jeremiah and Ezekiel, most of these prophets were poets and their oracles were delivered and have been preserved in poetic form (cf. Joyce 2007:8-9). However, prophets did in fact cast their oracles in genres other than poetry (Alter 1985:137). Alter's reasons for this exception are rather detailed and should not detain us here. He notes, for example, that the oracular vision is particularly one common type in which prose was preferred to poetry by the prophets (Alter 1985:137). This would be the case perhaps for obvious reasons: such visions demanded the stating of the setting, place, time, detailing of events and explanation of the enigmatic visions as, for example, in Ezekiel 1 and in Ezekiel 8-11. The contrast with Ezekiel 6 is therefore quite clear. Within the genres of prophetic oracles, Ezekiel 6 most appropriately qualifies as a monitory or judgemental oracle. According to Alter (1985:141), typical aspects that probably make prophecy best suited to poetry include the strategies of direct accusation, satire and the monitory evocation of impending disaster. Ezekiel 6 may fall in the category that Alter (1985:141) calls 'monitory evocation of impending disaster'. However, the Ezekiel 6 oracle is not simply a warning but a spelling of imminent disaster; it is not simply prediction, but a wrathful pronouncement of judgement and punishment. In any case, the message of Ezekiel 6 is a message that in many instances in the Bible would take the genre of prophetic poetry. The presentation of prophetic oracles in verse was probably ideal for many reasons, including that a considerable amount of information could be conveyed in relatively few words in dramatic and effective ways. In terms of time, space and progression, verse is more versatile than the more rigid prose. It allows one to play with words, emphasise, bring to remembrance, make associations, as well as communicate the emotions and the authority of the speaker, in relatively few words. Such a dramatic tool then should be well suited to prophecy, which in its versatile nature and wide applications had to reach the audience with the sufficient load that God intended it to have (Alter 1985:162).

Prophets in general would therefore have tended towards pronouncing their oracular messages in poetic form to their historical audiences, and indeed so would the editors and consequent readers tended to have read it. If the contemporary audiences of the prophets were used to hearing prophetic oracles in verse form, the temptation to shear towards a poetic structure any text that presented itself as a prophetic oracle (yet cast in a different genre), could have been enormous. But whilst the content of the Ezekiel 6 oracle is typically suited to verse, the reading of the text just faintly appears to give a poetic style.

\section{Ezekiel 6 as a list of judgements with echoes from Leviticus 26}

Ezekiel 6 is apparently a prophetic oracle that can further be described as cast in the form of lists of judgements or punishments with Israel as its target (Hummel 2005:200). This list of destructive events is at times coupled with further consequences and realisations, amongst them the fact that Israel 'will know that I am Yahweh'. Such a list-like characteristic of the judgements in Ezekiel 6 partly explains why the text has been identified with the lists or spellings of curses listed in Leviticus 26 (Hummel 2005:200), and indeed with the priestly deuteronomistic language in general. ${ }^{9}$ Within the corpus of microgenres in the biblical text that are typified as lists (such as genealogical lists, tribal lists and temple duty lists), Ezekiel 6 perhaps takes a place amongst them as 'an oracular list of prophetic judgements'.

There are more indications of a relationship, in terms of content and style, between parts of Ezekiel and Leviticus 26, with Ezekiel 4-6 being one of those parts (cf. Allen 1994:92-96). However, the relationships or echoes in terms of content only take the form of similarity in words and phrases within clusters of material between the two biblical passages. It may not be denied that if there was reduction at all in the book of Ezekiel, the extrapolation would have taken the form of bringing to the core of the text of Ezekiel 6, words and lines from priestly books, even subconsciously. If the redactors can be identified with what has been thought to be the 'school of Ezekiel' (Joyce 2007:13), 9.Hartley (1992:456-457) identifies the genre of Leviticus 26 as a list of curses and blessings. 
it would be possible that the reduction of the book was probably carried out by priests, acquainted with the scope of the law and the priesthood. Even more significant, for the purposes of the present subject at least, is the fact that a poetic base text has been reconstructed from the so-called redacted text of Leviticus 26 (cf. Allen 1994:93 who refers to Elliger 1966). This factor may strengthen the present hypothesis that there may have been poetic tendencies in the original message of Ezekiel 6, or that Ezekiel 6 could later have been sheared towards a more poetic form, in line perhaps with an unredacted Leviticus 26 text.

\section{Results and conclusions}

The foregoing analysis leaves us with the task of deciding on the nature of the genre of MT Ezekiel 6. It becomes apparent that in Ezekiel 6, one is not merely tasked with the need to decide whether the text is this or that type of genre, but is confronted with a seriously complex genre. Ezekiel 6 appears to be a list that is cast in the form of a prophetic oracle, dressed in eye-catching poetic parallelism, and yet also including elements of simple prosaic language. One plausible conclusion is that this text was worked in order to satisfy the redactors' perception of what form of genre the text should take, and one would like to believe that their intention was to give the text a poetical colour where that colour was initially only faint or accidental. These conclusions are by no means unquestionable. As Dillard and Longman (1994:27) have pointed out, it remains difficult to make a firm decision on this highly stylised text of Ezekiel 6. However, the witness of the GT plays an important role in this case. The GT, which we may understand to reflect the Hebrew text from which the MT was based, is certainly less developed in its poetics than the MT text.

An alternative view to this hypothesis that has been raised would be to see the translator of the GT as having made some omissions of what I have referred to as 'additional text' in the MT in this article (cf. Joyce 2007:45-46). Indeed, it may be that GT translators took such liberties upon themselves as to view the repetitions in their Hebrew Vorlage to be unnecessary, cumbersome, or garnishments by earlier editors, and thus acted on the perceived anomalies in the text by omitting the repetitions. However, that is a very difficult postulation, seeing the general literal character of translation apparent in the Septuagint of Ezekiel (Hubler 2007:946-947; Tov 1997:18-20). In view of such a constraint, one is persuaded that the text of Ezekiel may have gone through a process of literary development. In the context of the present discussion, the term 'literary development' becomes more specialised. It is taken here that the differences between the GT (earlier stage of Ezekiel) and the present form of the MT text (later stage of Ezekiel) are an indicator of significant literary development, in terms of genre or stylistics, rather than in terms of theological development.

\section{Acknowledgements Competing interests}

The author declares that he has no financial or personal relationship(s) that may have inappropriately influenced him in writing this article.

\section{References}

Allen, L.C., 1994, Ezekiel 1-19: Word biblical commentary, vol. 28, Word Books, Dallas. Alter, R., 1985, The art of biblical poetry, Basic Books, New York.

Berlin, A., 2008, The dynamics of biblical parallelism, rev. edn., W.B. Eerdmans, Grand Rapids.

Cooke, G.A., 1936, A critical and exegetical commentary on the Book of Ezekiel: International critical commentary, T \& T Clark, Edinburgh.

Dillard, R.B. \& Longman, T., 1994, An introduction to the Old Testament, Zondervan, Grand Rapids.

Elliger, K. \& Rudolph, W. (eds.), 2003, Biblia Hebraica Stuttgartensia (BHS), Deutsche Bibelgesellschaft, Stuttgart.

Freedman, D.N., 1980, Pottery, poetry and prophecy: Studies in Hebrew poetry, Eisenbraus, Winona Lake.

Garscha, J., 1974, Studien zum Ezchielbuch: Eine redaktionskritische untersuchung von Ez 1-39, Peter Lang, Frankfurt.

Goshen-Gottstein, M. \& Talmon, S., 2004, The Book of Ezekiel, The Hebrew University Magnes Press, Jerusalem.

Gray, G.B., 1972, The forms of Hebrew poetry: Considered with special reference to the criticism and interpretation of the Old Testament, Hodder and Stoughton, New York.

Greenberg, M., 1983, Ezekiel 1-20, Doubleday, New York.

Hartley, J.E., 1992, Leviticus: Word biblical commentary, Word Books, Dallas.

Hubler, N.J., 2007, 'IEZEKIEL, to the reader', in A. Pietersma \& B.G. Wright (eds.), A new English translation of the Septuagint, pp. 946-985, Oxford University Press, New York.

Hummel, H.D., 2005, Ezekiel 1-20: Concordia commentary, T \& T Clark, New York.

Joyce, P.M., 2007, Ezekiel: A commentary, T \& T Clark, New York.

Lust, J. (ed.), 1986, Ezekiel and his book: Textual and literary criticism and their interrelation, Leuven University Press, Leuven.

Lust, J., 2006, 'The Ezekiel text', in Y.A.P. Goldman, A. Van der Kooij \& R.D. Weis (eds.), Sofêr Mahîr: Essays in honour of Adrian Schenker offered by editors of Biblia Hebraica Quinta, pp. 162-164, Brill, Leiden.

Pietersma, A. \& Wright, B.G. (eds.), 1989, A new English translation of the Septuagint, Oxford University Prress, New York.

Pohlmann, K.-F., 1996, Das Buch Hesekiel (Ezechiel) Kapitel 1-19, Vandenhoeck \& Ruprecht, Göttingen.

Schulz, H., 1969, Das Todesrecht im Alten Testament: Studien zum Rechtsformen der Mot-Jumat-Sätze, de Gruyter, Berlin.

Stromberg, J., 2008, 'Observations on Inner-Scriptural Scribal Expansion in MT Ezekiel', Vetus Testamentum 58, 68-86. http://dx.doi.org/10.1163/156853307X237668

Tov, E., 1997, The text-critical use of the Septuagint in Biblical Research, Jerusalem, Simor.

Tov, E., 1999, The Greek and the Hebrew Bible: Collected essays on the Septuagint, Brill, Leiden.

Van Rooy, H.F., 2004, 'A new critical edition of the Hebrew Bible', Journal of Northwest Semitic Languages 30(1), 139-150.

Ziegler, J., 1977, Septuaginta: Vetus Testamentum Graecum XVI/1, 2nd edn., Vandenhoeck \& Ruprecht, Göttingen. 